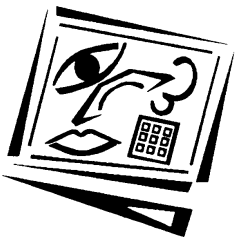

\title{
How do students use podcasts to support learning?
}

\author{
Sheila Scutter, Ieva Stupans, Tim Sawyer and Sharron King \\ University of South Australia
}

\begin{abstract}
Podcasting is used commonly recreationally and is now increasingly used in education. The technology for podcasting is readily available, easy to use and inexpensive, making it an attractive option for providing additional flexible learning resources for students. However, little is known about how podcasts are used by students and the implications for learning. This paper describes how podcasts were used by students in a medical radiation program. In common with many other health science programs, the medical radiation program has a large content load, particularly in first year where courses such as anatomy and physiology are introduced. Students generally used podcasts to review lecture content, especially when they had difficulty with understanding lectures or new terminology. Students generally listened to the recordings whilst viewing the lecture PowerPoint presentations on a home computer. Results from this study indicate that academics need to contemplate the introduction of instructional methods such as podcast lectures within the broader context of instructional goals.
\end{abstract}

\section{Podcasting in teaching}

"Podcasting" involves placing recorded material on a website from which it can be downloaded and listened to at a later time. Although originally developed as a way of providing access to recorded music by downloading, at a cost, from the Internet, podcasting is now used extensively by radio and television stations to make interviews or other interesting materials available to listeners (Bull, 2005). The cost of downloading from Internet sources has fallen, and most students have access to a computer and the Internet (Bray et al, 2007). Podcasts can be downloaded onto portable MP3 devices, for example, Apple iPods and replayed either through earphones or speakers.

The difference between podcasting and the uploading of audio recordings of lectures has been the subject of some discussion (Cebeci \& Tekdal, 2006). Podcasting may be said to involve editing and indexing of recorded lectures (e.g. Lee \& Chang, 2007), or uploading specifically designed audio clips, as opposed to the simple uploading of raw audio recordings onto a web site available to students. In this paper we refer to podcasting as the uploading of lectures onto the subject website, as quickly as possible after the lecture. For most lectures, the PowerPoint slides are also uploaded, usually before the lecture. Although technologies are now being used that automate the process of recording both audio and video recordings of lectures, we have used simple digital voice recorders operated by the lecturer, as teaching sessions often occur outside fully equipped lecture theatres.

Podcasting has been used by university academics in a number of ways. Provision through podcasting of complete lectures or short explanations of difficult concepts, 
explanation of assessment requirements, suggestions for further reading or provision of feedback on assessment tasks have been reported in higher education settings. Recorded material can be edited and indexed before uploading (Lee \& Chan, 2007), or "raw" lectures can be uploaded as soon as practical after presentation. These approaches are essentially focused on audio recording, however Palmer and Devitt (2007) developed interactive case based content for the $i$ Pod, and found that this also had great potential as a learning tool. There is little evidence as to which approach may be most appropriate for student learning (Maag, 2006; Cook 2009), although guidelines on how to use design principles to create podcasts that effectively support and enhance learning are being promulgated (e.g. Avgerinou, Salwach \& Tarkowski, 2007).

\section{Advantages of podcasting in education}

At first glance, there appear to be numerous advantages of podcasting lectures or other information to students in the academic environment. Students can download audio recordings of lectures from, for example, university course websites, to clarify areas that they may not have understood in those lectures. With relevance to cognitive load theories, the review of podcast lectures by students aligns with reported advantages of learning through multiple senses (Mayer \& Moreno, 2003). This work indicates that information received via one sensory channel is not processed and stored as well as information received from two, such as for example auditory and visual.

Podcasting may also accommodate a wide variety of learning strategies for students. While some students learn most effectively by taking notes during a lecture and reviewing these in their own study time, others learn more effectively by active listening, without taking notes (Boulos, Maramba \& Wheeler, 2006).

Podcasting of lectures provides additional resources for students who are unable to attend face to face classes. Students who are unable to attend lectures due to sickness, work or family responsibilities can listen to the lecture in conjunction with PowerPoint presentations, also commonly made available to students. In addition, as recognised by McKinney and Page (2009) students can be distracted in lectures by other factors, and may miss elements of what the lecturer is saying.

Podcasting as used in this project provides resources to all students that have previously been obtained by some students on an individual basis. In our University, it has been observed that in classes with a high proportion of English as a second language students (ESL), students have used tape recorders in lectures for many years; podcasting of lectures is a convenient option for these students.

Podcasting as used in this project requires only a digital voice recorder and software to upload the recordings. Thus the podcasting we used comes into the category of "mlearning" as defined by Dyson et al (2009). Software to download podcasts is readily available, and players to listen to them are becoming cheaper and better (Boulos, Maramba \& Wheeler, 2006). Thus the technology is cheap, easy to use and portable. Students can download podcasts onto MP3 players to listen to them in a variety of settings, or can listen to podcasts played directly from home or University computers. Therefore there is no impost upon the students to purchase new equipment or learn sophisticated technologies in order to access podcasts. In any event, most students now have MP3 players available to them (Kennedy, Judd, Churchward, Gray \& Krause, 2008). 


\section{Potential disadvantages of using podcasts}

There are a number of possible disadvantages for using podcasting. Some academic staff express a concern that students will no longer attend lectures and disengage from the academic environment. However, this has not been found to be the case in previous studies (von Konsky, Ivins \& Gribble, 2009). Fietze (2009) found that about half the student cohort would not consider the provision of podcasts as an opportunity to miss lectures. Although universities increasingly attempt to provide flexible learning opportunities for students, reduced engagement is clearly related to increased attrition and reduced success (Kuh, 2007; McInnes, 2001).

Podcasting has also been argued to lead to passive learning with students focussing on the audio facility rather than actively engaging with the lecture content (Palmer \& Devitt, 2007). Staff perceptions of disadvantages may stem from the current mainstream educational thinking, dominated by a constructivist view, which maintains that deep learning occurs when a learner is actively engaged in learning activities. Although listening to podcasts may be considered to be a passive skill, recent work on language learning and the value of podcasting in learning language describes listening as an active, creative and demanding process of selecting and interpreting information from auditory clues (Kavakiauskiene, 2008). Potentially the greater concern is not that of active or passive skills, but that podcasting of lectures for students may align with rote learning not conducive to student construction of meaning. This is a particularly relevant concern in the health sciences, where students in foundation years undertake "content heavy" courses such as anatomy and physiology which lend themselves to a rote learning approach. Although anatomy has been taught contextually in a problem based learning format involving active student learning, (e.g. Perac \& Armstrong, 1998, Grkovic, 2005) the current trend towards large common foundation courses for all health science students has resulted in a reversion to a more traditional, lecture based mode of teaching, with lesser opportunities for interactive learning.

\section{What is the best way to use podcasts?}

Although podcasting has been used in a number of education settings there is little known about how students use podcasts, whether they have the necessary information technology skills and equipment, and the overall impact that podcasting has on student learning. Brittain, Gllowacki, van Ittersum \& Johnson (2006) surveyed students' preferences for audio recordings (podcasts), synchronised with PowerPoints and video/audio format. Of interest was the finding that students preferred the podcasts to the other formats, possibly because they could listen to the podcasts while engaging in other tasks.

The aims of this study were therefore to investigate the way in which students used podcasts made available to them in courses in the Bachelor of Medical Radiation Program. An understanding of the way in which students use podcasts will inform the way in which podcasts can be used most effectively.

\section{Method}

In 2008 all academic staff teaching into the Medical Radiation program were offered the opportunity to participate in this trial. Several digital audio recorders were purchased at a cost of about $\mathrm{A} \$ 240$ each. The staff members were asked to start the 
recorder at the beginning of a teaching session to include any of the normal pre or post-class discussions of general information, for example information on assessment tasks, and including any "housekeeping" which occurs at the beginning of the session. The files uploaded for students to access were the "raw" recordings from the lectures, as we did not want to increase the workload of teaching staff, and also wanted the podcasts to be available as soon as possible after the lecture. The audio file was compressed to reduce the file size and then uploaded onto the appropriate (password protected) course web page.

The student evaluation component of the study was approved by the University of South Australia Human Research Ethics Committee (P080/07). This component used a questionnaire made available through the University of South Australia online survey tool, Tellus. The survey was distributed to all students in the medical radiation program (across the three year program, 160 students). The survey requested details concerning if, and when, students listened to podcasts, whether it impacted upon their attendance at lectures, and whether they had any difficulties using the podcasts. Likert scales were used for the students to indicate their responses. The questionnaire also allowed students to respond with free text comments.

The data was entered into Excel for analysis and reporting. Free text comments were read and themes extracted.

\section{Results}

Most academic staff teaching into the medical radiation program participated in the project by agreeing to podcast their lectures. A total of about 90 lectures were podcast during the first teaching period of the year. On several occasions the session was not successfully recorded, due to over-writing of previous recordings before they had been uploaded, failure to turn the recording device on, or unnoticed flat batteries.

Of a total of 160 students who received podcast lectures, 80 students $(50 \%)$ responded to the questionnaire, which was considered a good response rate for an online questionnaire. Of the respondents, $59(74 \%)$ were female and $21(26 \%)$ were male. This indicates a slight over-representation of female students, compared to the proportion in the cohort (62\% female). Of the 80 students responding, 64 had accessed a podcast lecture, and felt that listening to the podcasts had improved their learning either a little (33 students) or a lot (37 students). Eight of those who did not access a podcast indicated that they didn't feel it was necessary or did not have the time.

Fourteen of the students responding indicated that English was their second language (ESL). As the total number of ESL students in the program was nineteen, this indicates that a higher than represented proportion of ESL students responded to the survey.

Sixty students $(75 \%)$ indicated that if they knew the lecture was going to be podcast, then they were more likely to "skip" the lecture, although only 3 students indicated that they would always skip the lecture if they knew it was to be podcast. Many students $(60 \%)$ always or sometimes listened to the podcast if they were unable to attend the lecture.

As shown in Table 1, most students listened to the podcasts whilst viewing the PowerPoints that were routinely provided on the course web page. However, students 
also listened to the podcasts when they were on their way into University, doing other activities (such as household chores) and in conjunction with other study-related resources (e.g. looking at images during the podcast of an anatomy lecture). Although students did use the podcasts at other times, the use of the podcasts while viewing the lecture PowerPoints on a computer constituted the majority use. As students could select more than one option, the total in Table 1 is more than 80 .

Table 1: Student use of podcasts

\begin{tabular}{|l|c|}
\hline \multicolumn{1}{|c|}{ When do you listen to podcasts? } & Number of students \\
\hline On the way into University & 9 \\
\hline While I am doing other things & 14 \\
\hline In conjunction with other study related electronic media & 27 \\
\hline In conjunction with other electronic media (not study related) & 64 \\
\hline While looking at the lecture PowerPoints & 6 \\
\hline At other times & \\
\hline
\end{tabular}

As shown in Table 2, students indicated that the most useful aspects of having podcasts was being able to HEAR (emphasis in questionnaire) the lecture again, as opposed to having only PowerPoint presentations uploaded onto the course website. Also important was the flexibility of when they could listen to the lecture, which from Table 1 appears to be when they were looking at the PowerPoints from the lecture. In the comments section, students indicated that hearing the lectures again assisted them with pronunciation of unfamiliar terms. These comments came equally from local and international students. Only eleven students indicated that having the lectures podcast meant that that did not go to the lectures.

Table 2: The most useful aspects of podcasts to students

\begin{tabular}{|l|c|}
\hline What are the most useful aspects of podcasting lectures? & Number of students \\
\hline Flexibility of where I can listen to the lecture & 49 \\
\hline Being able to HEAR the lecture again & 56 \\
\hline Can just listen instead of also taking notes in lectures & 39 \\
\hline Clarification of issues or questions & 40 \\
\hline Means I don't have to go to lectures & 11 \\
\hline Revision for exams & 47 \\
\hline
\end{tabular}

As shown in Table 3, poor sound quality was the most common problem experienced by students when listening to podcasts. Initially, the digital recorder had been suspended by a lanyard around the lecturer's neck. Thus the recorder could move around and the noise from this movement interfered with the voice recording. This problem was rectified in later trials by using a clip on microphone. However, even with the clip on microphone the sound was sometimes of poor quality.

Table 3: Problems encountered with listening to podcasts

\begin{tabular}{|l|c|}
\hline What problems did you encounter with podcasting? & Number of students \\
\hline Difficulty accessing podcasts at University & 7 \\
\hline I don't have an MP3 player so had to listen at the computer & 16 \\
\hline Difficulty with accessing at home & 15 \\
\hline Sound quality was poor & 20 \\
\hline
\end{tabular}


Themes emerging from the comments made by students consisted of:

\section{Clarification of material presented in lectures}

Students found the podcasts to be useful in helping to clarify terminology and theoretical constructs, as explained in the following quote from a student comment:

Hearing a lecture a second time helps the theory to sink in and get the most out of the lecture. During lectures there is always times where you lack concentration and may miss bits that are vital to comprehension but within the lecture you don't want to interrupt the flow of the lecture by asking too many questions.

Podcasts were used when students received lectures from medical specialists:

Lecturers or doctors who came from hospitals had many informations in their PowerPoints and had more slides and also use medical terminology. At first when they give lectures, it doesn't get to my head, but after listening the podcast together with the PowerPoints, it helps me to understand what they really said (ESL student).

The podcasts appear to be important for ESL students as it appeared to support their conceptual understanding as well as pronunciation of new terminology. It also allowed them the opportunity to review the materials in their own time.

Sometimes when I read only the PowerPoint presentation, I get confused, then I refer to the text books, but hearing the podcast I could listen to the informations said by the lecturer once again and rectify my confusions (ESL student)

Learning by listening

Not only ESL students found this opportunity to re-listen to lecture content useful as a number of native English speaking students also commented that this additional listening time helped to support their learning:

I listened to one lecture twice and wrote the main points what was not in the PowerPoint presentation.

Useful for revision before exams

Students listened to the podcasts during exam preparation as they found that it increased their comprehension of difficult or complex topic areas:

during [revision for] the examinations, the podcast lecture is excellent, because once again we can hear it again and it will go into our heads.

I re-listened to every lecture at least once when revising for exams. I also spent about about 1 and a half hours listening to each lecture and pausing it constantly so I could read the text book and write notes. I think podcasting increased my grades enormously when I was doing this.

As the second student quote above confirms the opportunity to be able to pause the lecture, clarify understanding with additional resources such as the textbook greatly aided their overall understanding and hence learning outcomes.

Replacing attendance at lectures

As shown in Table 2 students did not rely on the podcasts as a substitute for missed lectures. For some students the choice to 'skip' the lecture was voluntary: 
I am able to skip very inconvenient lectures (for example when I only have one lecture that day) and this saves me about two hours in travelling time that I can then spend studying.

sometimes when I will be late to the uni, I usually skip the first class and this podcast lecture is also helpful.

However, for others the podcasts were an important backup when circumstances out of their control forced them to miss critical lectures.

it wasn't that I purposely missed lectures because I knew they would be podcast, but over the few weeks that I was sick and then recovering (and also a few times when work has interfered with timetable) its good to know the option is there if we miss a lecture, along with the lecture notes.

One student complained:

There has only been one lecture that I really wanted to listen to and it's not there. If podcasting is done it should be done for all lectures. It is annoying to have some lectures podcast and other not podcasted. Consistency makes things easier.

Another commented:

Would like to see every lecture podcast, even I don't use them, 'cause other people do, and the one lecture which might be missed due to unavoidable circumstances doesn't have to be met with "Oh my, is this going to be podcast" uncertainty. Given its relative ease of setting up, its not a big ask for such a large institution.

\section{Discussion}

Student support for continuation of podcasting was very positive, as has been found previously (Tynan \& Colbran, 2006). Indeed, students came to expect that podcasts would be provided, and were annoyed when they were not ("... it's not a big ask for such a large institution."). Although we did not ask students specifically about their IT skills or resources, it appeared that the technology was not a barrier for students.

The strong support from students for podcasting is likely to pressure academic staff to provide podcasts to achieve good feedback from students. Although beyond the scope of this paper, this issue is explored further in another paper (Elliot, Scutter \& King, 2009).

This study was undertaken to provide information to academic staff about how students use podcast lectures. This should ensure that students were being provided with materials that were useful and effective for their learning. Although many academic staff have embraced the technology and now routinely podcast lectures, there has been little consideration of how students use podcasts and whether they encourage student learning. From the findings of this study we hoped to better inform academics of effective ways to use podcasts. For example, if students listen to small segments of podcasts while travelling to University, then short explanations would be valuable. If on the other hand students sit in front of their home or library computer and listen to the podcast whilst viewing the lecture PowerPoint, then provision of podcast entire lectures would seem to be appropriate. What we found was that students used the podcasts to hear the lecture again and that they often did this while viewing the PowerPoint on their computer. This was an unexpected finding as we had expected that students would use MP3 players to listen to podcasts while "on the go". 
Although students indicated that they liked the flexibility of having lectures podcast, It would appear that this flexibility is with respect to time rather than situation. This is interesting in view of comments such as "... it is attractive for education because it potentially enables students to increase the number of hours of studying without necessarily having to remove something from their schedule such as doing household chores, or exercising." (Bell et al, 2007). A literature overview of usage from United States universities presented by Deal (2007) reports a similar "surprising" finding.

Student comments indicated that they felt they could learn more by hearing the lectures again so that information could get "into their heads". This supports anecdotes from the literature around podcasting "Proponents suggest that if students can replay information-dense lectures at their own convenience as often as they wish, they will ABSORB (our emphasis) the information better" (French, 2007). Although outside the scope of this article, discussion of learning approaches, such as rote learning, deserves attention. What is relevant to the work reported in this manuscript is the need to contemplate instructional methods such as podcast lectures within the broader context of instructional goals. It appears that by providing podcasts of lectures we may be encouraging an increasing dependence on the words of the academic getting "into their heads", probably to be recalled as needed. Indeed this is supported by the findings of McKinney and Page (2009) who used podcasting to supplement the teaching of pathophysiology to nursing students. Students in that study commented that the podcasts helped them to "retain information". Dyson et al (2009) describe the learning occurring from podcasts of lecture summaries as being "passive listening" and resulting in surface learning. Comments from students reinforced this to some extent, especially when students indicated that they needed to get "knowledge" "into their heads". Re-listening to lectures and taking additional notes from the audio recording would also appear to encourage a transmission mode of delivery and learning.

However, the issue of teaching "content heavy" courses such as anatomy remains problematic. Incorporating experiential learning into anatomy courses is difficult, especially as these courses tend to be taught in first year where students face the additional hurdles of transition to university. As the course is taught to students from a wide variety of programs, it is difficult to teach the content in the context of the students' eventual professions. Feedback and use of podcasts in the current study was much more positive than described by Dyson et al (2009). This may be because the podcasts we used were exact repeats of the lecture, rather than being scripted and edited versions of previous lectures. As commented by Dyson et al, this adds to the workload of academics and discourages renewing the resource on a yearly basis. In addition, students in the current study stressed the importance of hearing the same lecture again so that they could "fill in" parts they had missed. This may not have been possible with the podcasts used by Dyson et al. McKinney and Page (2009) also found that students liked to hear their own lecturer's voice, even if the resulting podcast was of a lesser quality.

Whether or not podcasting lectures will reduce student attendance has been discussed by previous authors (Frydenberg, 2006; Maag, 2006; Fietze, 2009). The results of the current study showed that some students were more likely to "skip" lectures if they knew they were going to be podcast, however their number was not large. Maag (2006) also found that the availability of podcasts had little impact on attendance. However, what is considered to be an important reduction in lecture attendance apparently 
differs between authors, as Fietze (2009) found that around half the class would consider not attending the lecture if it was to be podcast, but did not find this problematic. The very fact that some students may miss lectures that are to be podcast suggests that they saw them, in conjunction with the PowerPoint slides, to be a viable alternative to the lectures. As students are increasingly encouraged to be responsible for their own learning, perhaps it is these very choices that we should be encouraging. As discussed by Lee and Chan (2007), podcasts can enhance the learning of distance education students and as such should also improve learning for internal students.

With regard to the technology itself, technical failure is always a possibility when using electronic equipment. Students in this study indicated dissatisfaction when the expected access to podcasts was unfulfilled. This indicates that students need to be warned of the possibility of this happening at the commencement of a course. More sophisticated and automated recording of audio and visual input during lectures may overcome this problem, but is not at present an option at this University. As the group sizes in smaller programs such as Medical Radiation are small, it may be necessary to rely on less sophisticated equipment as it is usually the larger lecture theatres which are so equipped. A similar student dissatisfaction was reported by Brabazon (2006) who described students attending lectures without taking any notes with expectations of full resource provision by academic staff. No student reported that they could not access the podcasts because of lack of equipment or inability to download the podcasts due to the technological proficiency required.

Students reported learning benefits associated with the podcasts. This claim needs to be interpreted in the light of a recent study that has demonstrated that undergraduate exercise physiology students gained a direct benefit from being provided with supplementary materials, in the form of either printed text or podcasts. The use of podcasts provided little additional benefit over and above the printed text (Abt \& Barry, 2007). Therefore although students may feel that the podcasts improved their learning, their performance was the same as that of students provided with other types of additional extra study material. In contrast, podcasts have been shown to improve student performance compared to a traditional lecture format, in which PowerPoint slides were provided (McKinney, Dyck et al. 2009). The study by McKinney et al (2009) was limited to comparing performance from one short lecture; more research is needed into the actual outcomes from podcasting. Although students like having podcasts available, we should perhaps be questioning whether we are encouraging increasing dependence on lecture material rather than student-focused learning approaches. Other authors have described using podcasts to provide 5-10 minute "grabs" for students, but acknowledge that the production of such material represents considerable additional work for academics (Abt \& Barry, 2007).

The results of this study provide the academic staff involved in the project and also other academics with significant insight into actual student behaviours around their study habits. The degree of dependence of the students on resources such as podcast lectures was not anticipated and indicates the need of academics to thoughtfully incorporate such resources. Although Dobozy (2007) argues that students have a "right" to the knowledge held by academics and that academics have the skills to know how to effectively provide learning resources for students, pressure from students in the form of evaluation of academic staff may mean that the decisions made by academic staff about resources provided are not always pedagogically driven. 


\section{Conclusion}

Students listening to podcasts of lectures provided by academics tended to use the podcast in conjunction with replaying PowerPoint presentations that were also provided. It appears that students who used the podcasts wished to re-live the lecture experience. Although some students used podcasts with PowerPoints to replace attendance at lectures, this was not a general trend. Although students reported that the provision of podcasts improved their learning, it may be that the podcasts encourage passive rather than active learning. It is suggested that rather than podcasting complete lectures, academics consider using podcasts to explain key points.

\section{References}

Abt, G. \& T. Barry (2007). The quantitative effect of students using podcasts in a first year undergraduate exercise physiology module. Bioscience Education e-Journal, 10. http://www.bioscience.heacademy.ac.uk/journal/vol10/beej-10-8.aspx

Avgerinou, M., Salwach, J. \& Tarkowski, D. (2007). Information design for podcasts. In C. Montgomerie \& J. Seale (Eds.), Proceedings of World Conference on Educational Multimedia, Hypermedia and Telecommunications 2007 (pp. 754-756). Chesapeake, VA: AACE.

Barry, T. \& Abt, G. (2007). A strategy for using podcasts for teaching and learning in the biosciences. Podcasting Exercise Physiology - Enhancing the student experience: Podcasting Strategy. Centre for Bioscience, The Higher Education Academy, http://www.bioscience.heacademy.ac.uk/ftp/tdf/barrystrategy.pdf

Bell, T., Cockburn, A., Wingkvist, A. \& Green, R. (2007). Podcasts as a supplement in tertiary education: An experiment with two computer science courses. In D. Parsons and H. Ryu (Eds), Proceedings Mobile Learning Technologies and Applications (MoLTA) 2007, Massey University. http: / / molta.massey.ac.nz/ massey/fms / / Molta/Bell.pdf

Boulos, M. N. K., Maramba, I. \& Wheeler, S. (2006). Wikis, blogs and podcasts: A new generation of web-based tools for virtual collaborative clinical practice and education. BMC Medical Education, 6:41. http: / / www.biomedcentral.com/1472-6920/6/41

Brabazon, T. (2006). Socrates in earpods? The ipodification of education. Fast Capitalism, 2(1). http:/ / www.uta.edu/huma/agger/fastcapitalism/2_1/brabazon.html

Brittain, S., Gllowacki, P., van Ittersum, J. \& Johnson, L. (2006). Podcasting lectures: Formative evaluation strategies helped identify a solution to a learning dilemma. EDUCAUSE Quarterly, No 3, 24-31. http: / / www.educause.edu/EDUCAUSE+Quarterly / EDUCAUSE QuarterlyMagazineVolum/PodcastingLectures/157413

Bull, G. (2005). Podcasting and the long tail. Learning and Leading with Technology, November 2005, 24-27. [verified 20 Mar 2010] http: / / www.eric.ed.gov:80/ ERICDocs/data/ ericdocs2sql / content_storage_01/0000019b/80/1e/1d/fc.pdf

Campbell, G. (2005). There's something in the air: Podcasting in education. EDUCAUSE Review, 40(6), 32-47. http: / / www.educause.edu/EDUCAUSE+Review/EDUCAUSEReview MagazineVolume40/TheresSomethingintheAirPodcast/158014

Cebeci, Z. \& A. Tekdal (2006). Using podcasts as audio learning objects. Interdisciplinary Journal of Knowledge and Learning Objects, 2, 47-57. http: / / ijklo.org/Volume2/v2p047-057Cebeci.pdf 
Chan, A. \& Lee, M. (2005). An MP3 a day keeps the worries away: Exploring the use of podcasting to address preconceptions and alleviate pre-class anxiety amongst undergraduate information technology students. In D. Spennemann \& L. Burr (Eds), Good practice in practice. Proceedings of the Student Experience Conference (Charles Sturt University) Wagga Wagga, NSW Sept 2005 pp 59-71. http:/ / www.csu.edu.au/division/studserv/sec/papers/chan.pdf

Cook, D. A. (2009). The failure of e-learning research to inform educational practice, and what we can do about it. Medical Teacher, 31(2), 158-162.

Deal, A. (2007). Podcasting: A teaching with technology white paper. Office of Technology for Education \& Eberly Center for Teaching Excellence, Carnegie Mellon University. Verified 20 Mar 2010] http:/ / www.cmu.edu/teaching/ resources/PublicationsArchives/Studies Whitepapers / Podcasting_Jun07.pdf

Dobozy, E. (2007). The digitalisation of pedagogy: Dressed-up consumerism, techno-utopianism or genuine benefit? Proceedings Australian Association for Research in Education Conference, Edith Cowan University. Perth WA. http:/ / www.aare.edu.au/07pap/dob07067.pdf

Dyson, L., Litchfield, A., Lawrence, E., Raban, R. \& Leijfdekkers, P. (2009). Advancing the mlearning research agenda for active, experiential learning: Four case studies. Australasian Journal of Educational Technology, 25(2), 250-267.

http: / / www.ascilite.org.au/ajet/ajet25/dyson.html

Elliot, E., King, S. \& Scutter, S. (2009). To podcast or not to podcast? Pedagogical decision making in the use of new technologies. In Proceedings Uniserve Science Annual Conference, 30 Sep - 2 Oct. http:/ / science.uniserve.edu.au/images/ content/2009_papers/ elliot1.pdf

Fietze, S. (2009). Podcast in higher education: Students usage behaviour. In Same places, different spaces. Proceedings ascilite Auckland 2009.

http: / / www.ascilite.org.au/conferences / auckland09/procs/fietze.pdf

Frydenberg, M. (2006). Principles and pedagogy: The two $\mathrm{P}^{\prime} \mathrm{s}$ of podcasting in the information technology classroom. Proceedings of ISECON, Champagne, Nov 2006 Vol 23 pp 1-10. http: / / proc.isecon.org/2006/3354/ ISECON.2006.Frydenberg.pdf

Grkovic, I. (2005). Transition of the medical curriculum from classical to integrated: Problembased approach and Australian way of keeping academia in medicine. Croation Medical Journal, 46, 16-20.

Kennedy, G. E., Judd, T. S., Churchward, A., Gray, K. \& Krause, K.-L. (2008). First year students' experiences with technology: Are they really digital natives? Australasian Journal of Educational Technology, 24(1), 108-122. http:/ / www.ascilite.org.au/ajet/ajet24/ kennedy.html

Kuh, G. D. (2007). What matters to student success in the first year of university? 10th Pacific Rim First Year in Higher Education Conference 2007. Brisbane Australia. http:/ / www.fyhe.com.au/past_papers/papers07/abstracts/george_kuh.html

Lee, M. \& Chan, A. (2007). Reducing the effects of isolation and promoting inclusivity for distance learners through podcasting. Turkish Online Journal of Distance Education, 8(1). http: / / tojde.anadolu.edu.tr/tojde25/articles/Article_7.htm

Maag, M. (2006). Podcasting and MP3 players: Emerging education technologies. Computers, Informatics, Nursing, 24(1), 9-13.

McInnes, C. (2001). Signs of disengagement? The changing undergraduate experience in Australian universities. Inaugural Professorial Lecture, The University of Melbourne.

http: / / repository.unimelb.edu.au/10187/ 1331 
McKinney, D., Dyck, J. et al. (2009). iTunes University and the classroom: Can podcasts replace professors? Computers $\mathcal{E}$ Education, 52(13), 617-623.

McKinney, A. A. \& Page, K. (2009). Podcasts and videostreaming: Useful tools to facilitate learning of pathophysiology in undergraduate nurse education? Nurse Education in Practice, 9(6), 372-376.

Palmer, E. \& Devitt, P. (2007). A method for creating interactive content for the IPod, and its potential use as a learning tool: Technical advances. BMC Medical Education, 7: 32 http: / / www.biomedcentral.com/1472-6920/7/32

Percac, S. \& Armstrong, E. G. (1999). Introducing a problem-based anatomy course in a traditional curriculum: A Croatian experience. Medical Teacher, 20, 114-119.

Tynan, B. \& Colbran, S. (2006). Podcasting, student learning and expectations. In Whose learning, Whose technology? Proceedings ascilite Sydney 2006.

http: / / www.ascilite.org.au/conferences/sydney06/proceeding/pdf_papers/p132.pdf

von Konsky, B. R., Ivins, J. \& Gribble, S. J. (2009). Lecture attendance and web based lecture technologies: A comparison of student perceptions and usage patterns. Australasian Journal of Educational Technology, 25(4), 581-595.

http:/ / www.ascilite.org.au/ajet/ajet25/vonkonsky.html

Whitehead, D. E. J., Bray, D. \& Harries, M. (2007). Not just music but medicine: Podcasting surgical procedures in otolaryngology. Clinical Otolaryngology, 32, 3-6.

Dr Sheila Scutter (corresponding author)

School of Health Sciences, University of South Australia

Email: Sheila.Scutter@unisa.edu.au Web: http: / / people.unisa.edu.au/Sheila.Scutter

Associate Professor Ieva Stupans

School of Pharmacy and Biomedical Sciences, University of South Australia

Email: Ieva.Stupans@unisa.edu.au Web: http: / / people.unisa.edu.au/Ieva.Stupan

Mr Tim Sawyer

School of Health Sciences, University of South Australia

Email: tim.sawyer@unisa.edu.au Web: http:/ / people.unisa.edu.au/Tim.Sawyer

Dr Sharron King, School of Health Sciences, University of South Australia Email: sharron.king@unisa.edu.au Web: http:/ / people.unisa.edu.au/Sharron.King 